\title{
Availability of Heavy Metals in Borg Elarab Soil and Their Uptake by Potato Plants (Solanum tuberosum L.) Irrigated with Wastewater
}

\author{
S.A.E. Abdelrazek* and A.E.M. Shouman ** \\ * Soil Salinity Department, Alexandria Soil, Water and Environment Research Institute, \\ Agriculture Research Center, Giza, Egypt \\ ** Institute of Environment Studies Research -Ain Shams University, Egypt \\ Corresponding author S.A.E. Abdelrazek, Email: Samad saad@yahoo.com
}

\begin{abstract}
To demonstrate availability of heavy metals in soil uptake by potato plants irrigated with wastewater. The wastewater near Sayed Darwish village, Borg Elarab City, Alexandria, Egypt was collected. The measured heavy metals in the wastewater were compared with the permissible levels stated in environmental regulations, Law No. 48 of 1982 concerning the protection of the Nile River and waterways from pollution. Heavy metals accumulation in potato irrigated with wastewater as following: $F e(140 \mathrm{mg} / \mathrm{kg}), \mathrm{Mn}(33.2 \mathrm{mg} / \mathrm{kg}), \mathrm{Zn}(31.1 \mathrm{mg} /$ $\mathrm{kg})$, Cu $(6.3 \mathrm{mg} / \mathrm{kg})$, Co $(1.1 \mathrm{mg} / \mathrm{kg}), \mathrm{Ni}(3.2 \mathrm{mg} / \mathrm{kg}), \mathrm{Pb}(2.4 \mathrm{mg} / \mathrm{kg})$, all item are more than allowable limits, concentrations of these available heavy metals in the surface layer $(0-5 \mathrm{~cm})$ of irrigated soil of waste water Fe $(22.9 \mathrm{mg} / \mathrm{kg}), \mathrm{Mn}(18.6 \mathrm{mg} / \mathrm{kg}), \mathrm{Zn}(18.2 \mathrm{mg} / \mathrm{kg}), \mathrm{Cu}(4.3$ $\mathrm{mg} / \mathrm{kg})$, Co $(1.7 \mathrm{mg} / \mathrm{kg}), \mathrm{Ni}(4.1 \mathrm{mg} / \mathrm{kg}), \mathrm{Pb}(4.1 \mathrm{mg} / \mathrm{kg})$, compared with irrigated soil from artesian water Fe $(11.2 \mathrm{mg} / \mathrm{kg}), \mathrm{Mn}(9.5 \mathrm{mg} / \mathrm{kg}), \mathrm{Zn}(19.1 \mathrm{mg} / \mathrm{kg})$, Cu $(6.2 \mathrm{mg} / \mathrm{kg})$, Co $(1.2 \mathrm{mg} /$ $\mathrm{kg})$, Ni $(0.2 \mathrm{mg} / \mathrm{kg}), \mathrm{Pb}(1.5 \mathrm{mg} / \mathrm{kg})$ respectively. Potato plants irrigated with such wastewater specially wastewater not safe for human and animal consumption accordingly, the study suggests and recommends remediation of wastewater using physical, chemical and/or biological methods.
\end{abstract}

Keywords: Heavy metals, Borg El arab, waste water, potato plant

\section{INTRODUCTION}

Day et al. (1979) found that the extractable phosphorous was higher in soils irrigated with the pump water - wastewater mixture than in soils irrigated with pump water. Also, Hinasly et al. (1979) indicated that there exists a tremendous increase in the concentrations of $\mathrm{Zn}, \mathrm{Cu}, \mathrm{Fe}$, and $\mathrm{Mn}$ in sandy soils irrigated with sewage water and similar results were obtained by (El - Nennah et al.,1982).

Elsokkary (1980) found that contents of $\mathrm{Zn}, \mathrm{Pb}, \mathrm{Cd}$, and $\mathrm{Co}$ in some plants (wheat grain, radish, pepper, cabbage, barley and Jews mallow) depend on its concentration in industrially polluted soil. El- Nennah et al. (1982) found that continuous usage of sewage effluents in irrigation, increased markedly available $\mathrm{p}$, soluble $\mathrm{B}$ and DTPA- extractable $\mathrm{Cd}, \mathrm{Co}, \mathrm{Cr}, \mathrm{Cu}$ and $\mathrm{Pb}$ in soil.

Abdel-Tawab (1985) reported that using polluted water in irrigation increased the concentration of $\mathrm{Mn}, \mathrm{Zn}$, and $\mathrm{Pb}$ in soils located beside the factories at Helwan. Khalil (1990) reported that the prolonged period of irrigation with sewage water has markedly increased the amount of $\mathrm{Fe}, \mathrm{Zn}, \mathrm{Mn}, \mathrm{Cu}, \mathrm{Pb}$ and $\mathrm{Ni}$ in plants grown on Abu Rawash area, but the trace element levels in the leaves and juice fruits citrus and field crops (faba been, lupine) are below the standard level values 
Water pollution remains a serious global problem, with impacts on the health of fresh water ecosystems and the human communities. The traditional pollution sources like sewage, industrial wastes and pollutants like pesticides and inorganic fertilizers have combined to degrade water quality, particularly near urban industrial centers and intensive agriculture areas (UNEP/ GEMS, 1995).

Abdel- Sabour et al. (2000) showed that the prolonged irrigation with heavy metals contaminated wastewater increased significantly heavy metals contents of the tested soil Moreover, data showed that heavy metals contents in either rice or sorghum plants grown in polluted soils are higher in most cases compared with the control. Abdelrazek (2014) found that the accumulation of heavy metals was pronounced in soil. Moreover, data showed that heavy metals contents in either rice or sorghum plants grown in polluted soils are higher most cases compared with the control.

Elgala et al. (2003) mentioned that the total Fe, Zn, Cu, Co, Ni and Pb concentrations in the upper $10 \mathrm{~cm}$ layer increased by about 1.4, 4.5, 1.1, 2.7, 2.8 and 5.5 times in Musturud soil, which irrigated with industrial wastewater; while in Elgabal-Elasfar soil, which irrigated with sewage water, it reached to 9.0, 3.3, 10.6, 9.6, 6.9 and 3.2 times that of soil irrigated with Nile water. In many countries of the world, treated wastewater is considered as an important element in water resources planning (Abd-El-Naim et al.,1989). Chang et al. (1984) reported that heavy metals tend to accumulate in the surface soil layers and that strong binding force with clay minerals and organic matter limit their movement. These results were in good agreement with those reported by AlLahham et al. (2003), Abbas et al. (2007) and Madrid et al. (2007).

As soil health emphasizes the holistic approach to soil management, it must include water indicators, as the use of wastewater where it was sometimes the only source of irrigating crops, preferable by farmers (Abdelrazek, 2007 and Idowu et al. 2007). Industrial liquid wastes are more varied and more concentrated and contain certain various acids, alkalis chemical contaminants, oil, coarse solids, and other constituents. Dissolved materials include inorganic nutrients (Phosphate, ammonium, nitrate, sodium, etc). Toxic wastes (heavy metals mostly from industry $\mathrm{Cu}, \mathrm{Zn}, \mathrm{Hg}, \mathrm{Pb}, \mathrm{Cd}, \mathrm{Cr}$, Co, As etc.) and non-biodegradable organic chemicals (Mohamed and Abdelrazek, 2014).

Shouman (2015) found that in El-amia drain the accumulated amounts of heavy metals in soil were in the following order: $\mathrm{Pb}$ (ranged from $6.3-7.9 \mathrm{mg} \mathrm{kg}{ }^{-}$ $\left.{ }^{1}\right) \geq \mathrm{Ni}\left(6.2-7.9 \mathrm{mg} \mathrm{kg}^{-1}\right)>\mathrm{Co}\left(4.7-7.1 \mathrm{mg} \mathrm{kg}^{-1}\right)>\mathrm{Cd}\left(3.8-5.3 \mathrm{mg} \mathrm{kg}^{-1}\right)$.

The objectives of this study were to evaluate a wastewater for irrigation and its effect on the distribution of total and chemically available heavy metals in Silt Clay Loam soil to the depth of $150 \mathrm{~cm}$ as well as to evaluate the accumulation of such elements in certain grown crop in Borg El arab area. 


\section{MATERIALS AND METHODS}

Study area: Borg El arab, 48 Kilometer west of Alexandria - Marsa Matruh road. It lays approximately between latitudes $30^{\circ} 45^{\circ}$ and $30^{\circ} 55^{\circ} \mathrm{N}$, and longitudes $29^{\circ} 30^{\circ}$ and $29^{\circ} 50^{-} \mathrm{E}$ The study area covered about 504 Hectare planted potatoes and located near alex- cairo desert road and alex-Matrouh road way as shown in Fig 1.

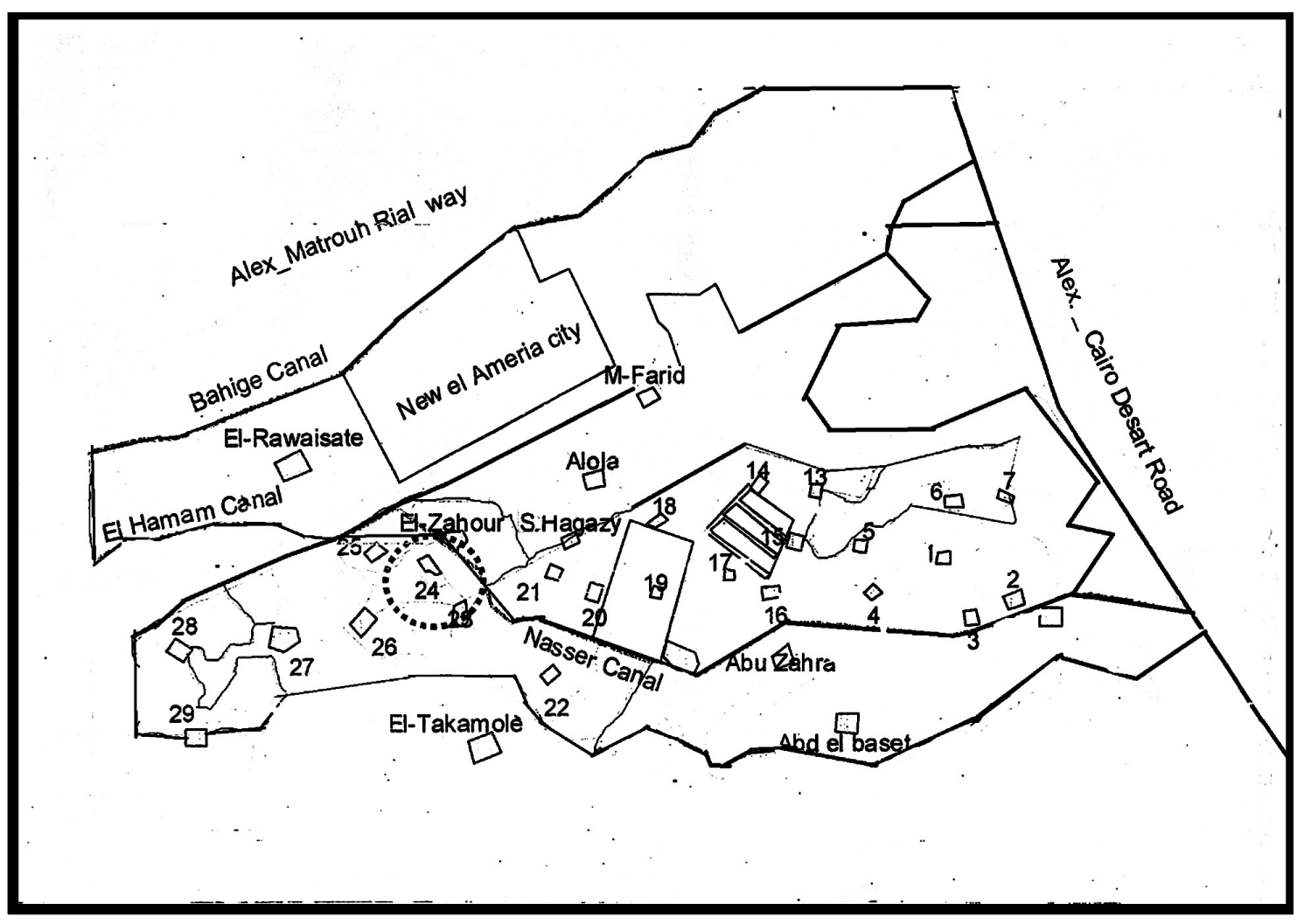

Fig(1). Location map of the study area

Wastewater( $1,7,6,5,13,14,17,15,22,23,25,28,9,10)$

Artesian water(2,3,4,16,18,20,21,24,26,29,27,8,11,21)

Samples: Soil samples from two sites were collected from Borg Elarab area. The first site is irrigated with artesian water and the second site is irrigated with wastewater in the same area (Cast directly on the irrigation canals). In each site, five soil profiles were dug to the depth of $150 \mathrm{~cm}$ and soil samples were collected from successive depths $(0-5,5-10,10-30,30-60,60-90,90-150 \mathrm{~cm})$. These samples represent variations in cropping patterns, and different irrigation water sources. The present cropping patterns include potatoes (Solanum tuberosum L.). Twelve water samples from irrigation water, six samples from the Artesian and six samples from the wastewater were collected for chemical analysis. Twelve plant samples were collected from each side, six samples from the plants which irrigated from Artesian water and six samples from the plants which irrigated from wastewater were collected for chemical analysis. 
Analysis: The collected plant samples were washed with tap water, $10^{-4} \mathrm{M} \mathrm{HCl}$ solution, and ionized water, then oven dried at $65^{\circ} \mathrm{C}$ for 48 hours. Plant materials were ground and mixed well and kept for $\mathrm{Fe}, \mathrm{Zn}, \mathrm{Cu}, \mathrm{Co}, \mathrm{Ni}$ and $\mathrm{Pb}$ analysis (Rawa, 1973).

Total heavy metals contents of $\mathrm{Fe}, \mathrm{Zn}, \mathrm{Cu}, \mathrm{Co}, \mathrm{Ni}$ and $\mathrm{Pb}$ in soil were determined after digestion with hydrofluoric/ perchloric acids mixture (Jackson, 1958) .

Available heavy metals were evaluated by extracting the soil with DTPA according to Lindsay and Norvell (1978) and the metals in the extract were determined using an atomic absorption spectrophotometer.

The physical and chemical properties of the soil samples were determend according to the method of (Richards, 1954), Table 1

Also, some chemical composition of the two water sources were measured and presented in Table 2.

Table(1). Some physical and chemical characteristics of the selected soils irrigated with artesian and wastewater.

\begin{tabular}{lcc}
\hline \multicolumn{1}{c}{ Parameter } & $\begin{array}{c}\text { Soil irrigated with } \\
\text { artesian water }\end{array}$ & $\begin{array}{c}\text { Soil irrigated with } \\
\text { wastewater }\end{array}$ \\
\hline $\mathrm{pH}$ & 8.23 & 7.62 \\
$\mathrm{EC} \mathrm{dSm}^{-1}$ & 5.71 & 2.51 \\
$\mathrm{CaCO}_{3} \%$ & 39 & 28 \\
$\mathrm{OM} \%$ & 0.55 & 1.24 \\
$\mathrm{CEC} \mathrm{cmolc.kg}{ }^{-1}$ & 10 & 19 \\
Sand\% & 76 & 32 \\
Silt\% & 1 & 44 \\
Clay\% & 23 & 24 \\
\hline \multicolumn{1}{c}{ Textural class } & Silt Clay Loam & Loam \\
\hline
\end{tabular}


Table (2). Some chemical composition of the two water sources in Borg Elarab area

\begin{tabular}{|c|c|c|c|c|c|}
\hline Parameter & units & $\begin{array}{c}\text { FAO * } \\
\text { guidelines }\end{array}$ & $\begin{array}{l}\text { Law No. } \\
48 \text { of1982 }\end{array}$ & $\begin{array}{l}\text { Artesian } \\
\text { water }\end{array}$ & Wastewater* \\
\hline $\mathrm{pH}$ & & $6.5-8.4$ & $7-8.5$ & 8.8 & 7.3 \\
\hline $\mathrm{EC}$ & $\mathrm{dS} \cdot \mathrm{m}^{-1}$ & $<3$ & & 2.53 & 3.80 \\
\hline TDS & ppm & $<450$ & 500 & 1619.2 & 2432 \\
\hline COD & $\mathrm{mg} \mathrm{L}^{-1}$ & $====$ & $>10$ & n.d & 250 \\
\hline BOD5 & $\mathrm{mg} \mathrm{L}^{-1}$ & $=====$ & $>5$ & 6.5 & 563.7 \\
\hline $\mathrm{Ca}^{2+}$ & $\mathrm{mg} \mathrm{L}^{-1}$ & $=====$ & ------ & 5.12 & 7.81 \\
\hline $\mathrm{Mg}^{2+}$ & $\mathrm{mg} \mathrm{L}^{-1}$ & $=====$ & ------ & 1.9 & 7.3 \\
\hline $\mathrm{Na}+$ & $\mathrm{mg} \mathrm{L}^{-1}$ & $<70$ & ----- & 7.1 & 13.10 \\
\hline Total N & $\mathrm{mg} \mathrm{L}^{-1}$ & $<30.0$ & $>1$ & 5.11 & 75.2 \\
\hline $\mathrm{NO}^{-}$ & $\mathrm{mg} \mathrm{L}^{-1}$ & 10 & $>45$ & 1.13 & 16.82 \\
\hline $\mathrm{PO}=4$ & $\mathrm{mg} \mathrm{L}^{-1}$ & 8.6 & 1 & 0.07 & 4.34 \\
\hline B & $\mathrm{mg} \mathrm{L}^{-1}$ & $<1.0$ & ----- & 0.12 & 0.28 \\
\hline $\mathrm{Cl}^{-}$ & $\mathrm{mg} \mathrm{L}^{-1}$ & $<140$ & ----- & 5.91 & 14.9 \\
\hline $\mathrm{HCO}_{3}^{-}$ & $\mathrm{mg} \mathrm{L}^{-1}$ & $<90$ & ----- & 5.94 & 4.32 \\
\hline $\mathrm{Fe}$ & $\mathrm{mg} \mathrm{L}^{-1}$ & 5.0 & $>1$ & 2.81 & 3.69 \\
\hline $\mathrm{Mn}$ & $\mathrm{mg} \mathrm{L}^{-1}$ & 0.2 & $>0.5$ & 0.95 & 1.32 \\
\hline $\mathrm{Zn}$ & $\mathrm{mg} \mathrm{L}^{-1}$ & 2.0 & $>1$ & 0.90 & 1.15 \\
\hline $\mathrm{Cu}$ & $\mathrm{mg} \mathrm{L}^{-1}$ & 0.2 & $>1$ & 0.31 & 0.64 \\
\hline $\mathrm{Ni}$ & $\mathrm{mg} \mathrm{L}^{-1}$ & 0.2 & ----- & 0.21 & 0.82 \\
\hline Co & $\mathrm{mg} \mathrm{L}^{-1}$ & 0.05 & ----- & 0.11 & 0.3 \\
\hline $\mathrm{Cd}$ & $\mathrm{mg} \mathrm{L}^{-1}$ & 0.01 & $>0.01$ & 0.13 & 0.46 \\
\hline $\mathrm{Pb}$ & $\mathrm{mg} \mathrm{L}^{-1}$ & 5.0 & $>0.05$ & 0.41 & 0.62 \\
\hline SAR & & $<9.0$ & ----- & 3.80 & 4.76 \\
\hline
\end{tabular}

n.d = not detected ${ }^{*}$ Fair et al. 1971), FAO (1976), WHO (1993)

*Source of wastewater (artificial water from Industrial City Borg Elarab and sewage water from Mary Mina a church)

\section{RESULTS AND DISCUSSIONS}

\section{I-Total Heavy metals content in soils:}

Data in Table 3 show the total amounts of $\mathrm{Fe}, \mathrm{Mn}, \mathrm{Zn}, \mathrm{Cu}, \mathrm{Co}, \mathrm{Ni}$ and $\mathrm{Pb}$ in different layers of the investigated soils profiles. Data reveal that the total content of these elements differed according to water source used for irrigation. These results are in agreement with the findings of Pescod (1992) who found that after 6 years of continually applying sludge at a cropland disposal site over $90 \%$ of the applied heavy metals were found in the 0 to $15 \mathrm{~cm}$ soil depth. This depth is practically within the plow layer. If the soil still irrigated with this water for the long time, the root zone could be polluted with $\mathrm{Zn}, \mathrm{Cu}, \mathrm{Ni}$ and $\mathrm{Pb}$. 
Table (3). Total and DTPA-extractable heavy metals, $\mathrm{mgkg}^{-1}$ in the studied soils as affected by source of irrigation and soil depth

\begin{tabular}{|c|c|c|c|c|c|c|c|c|c|c|c|c|c|c|}
\hline \multirow[t]{2}{*}{$\begin{array}{l}\text { Depth } \\
\text { (cm). }\end{array}$} & \multicolumn{2}{|c|}{$\mathbf{F e}$} & \multicolumn{2}{|c|}{ Mn } & \multicolumn{2}{|c|}{$\mathrm{Zn}$} & \multicolumn{2}{|c|}{$\mathrm{Cu}$} & \multicolumn{2}{|c|}{ Co } & \multicolumn{2}{|c|}{$\mathrm{Ni}$} & \multicolumn{2}{|c|}{$\mathbf{P b}$} \\
\hline & Total & DTPA & Total & DTPA & Total & DTPA & Total & DTPA & Total & DTPA & Total & DTPA & Total & DTPA \\
\hline \multicolumn{15}{|c|}{ Soil irrigated with wastewater } \\
\hline $0-5$ & 625 & 22.9 & 37.27 & 18.6 & 31.54 & 18.2 & 8.95 & 4.3 & 1.93 & 1.7 & 5.89 & 4.1 & 6.88 & 4.1 \\
\hline $5-10$ & 70.4 & 23.2 & 32.80 & 14.2 & 31.74 & 17.2 & 7.3 & & 1.84 & 1.5 & 5.67 & 4.3 & 6.47 & 2.7 \\
\hline $10-30$ & 62.2 & 20.1 & 34.98 & 10.4 & 19.68 & 11.3 & 7.75 & 3.8 & & 0.6 & 3.36 & 2.9 & 6.26 & 2.8 \\
\hline $30-60$ & 48.5 & 9.2 & 23.12 & 7.5 & 19.64 & 9.3 & 6.95 & 2.4 & 0.68 & 0.2 & 4.96 & 3.6 & 3.69 & 2.1 \\
\hline $60-90$ & 39.8 & 10.2 & 36.38 & 6.2 & 6.51 & 5.96 & 5.65 & 2.6 & 0.97 & 0.5 & 3.51 & 2.1 & 2.88 & 1.6 \\
\hline $90-150$ & 46.4 & 5.5 & 23.10 & 4.2 & 15.20 & 7.2 & 4.86 & 1.2 & 0.88 & 0.7 & 2.63 & 1.6 & 4.49 & 1.1 \\
\hline \multicolumn{15}{|c|}{ Soil irrigated with artesian water } \\
\hline $0-5$ & 40.9 & 11.2 & 15.58 & 9.5 & 23.23 & 19.1 & 13.59 & 6.2 & 1.65 & 1.2 & 0.98 & 0.2 & 2.39 & 1.5 \\
\hline $5-10$ & 50.8 & 9.3 & 10.37 & 9.6 & 14.13 & 8.3 & 2.84 & 1.9 & 1.98 & 1.4 & 0.87 & 0.5 & 2.42 & 1.6 \\
\hline $10-30$ & 40.7 & 9.2 & 15.66 & 7.2 & 15.14 & 5.6 & 1.69 & 1.4 & 1.64 & 0.8 & 0.98 & 0.5 & 2.57 & 1.1 \\
\hline $30-60$ & 33.7 & 7.2 & 15.36 & 7.6 & 15.13 & 5.3 & 1.48 & 0.6 & 1.38 & 0.6 & 0.94 & 0.1 & 2.62 & 1.0 \\
\hline $60-90$ & 49.7 & 4.6 & 14.24 & 5.3 & 6.12 & 4.4 & 1.75 & 0.9 & 1.37 & 0.2 & 0.70 & 0.1 & 1.75 & 0.8 \\
\hline $90-150$ & 49.7 & 2.3 & 13.25 & 3.4 & 5.13 & 1.2 & 1.75 & 0.3 & 0.65 & 0.1 & 0.63 & 0.2 & 1.33 & 0.7 \\
\hline
\end{tabular}

\section{II- DTPA-extractable heavy metals in soils:}

Results given in Table 4 show the DTPA-extractable Fe, Mn, Zn, Cu, Co, $\mathrm{Ni}$ and $\mathrm{Pb}$ in the successive layers of Borg ELarab soil as affected by irrigation with artesian water and wastewater. Chemically available values for different heavy metals vary according to water source and decreased with increasing soil depth. The increasing extractability of the concerned heavy metals in the soil irrigated with wastewater could be attributed to increasing the total contents. Beside the relatively low $\mathrm{pH}$ values (increase of acidity in wastewater in this soil also in Table (4) the chemically available $\mathrm{Mn}, \mathrm{Zn}$ and $\mathrm{Cu}$ showed the highest values in the upper layer for soil irrigated with wastewater compared to other elements Fig 2.

Table (4). available index ratio* for different heavy metals in the studied soils as affected by source of irrigation and soil depth

\begin{tabular}{cccccccc|cccccccc}
\hline \multicolumn{1}{c|}{ Soil irrigated with wastewater water } & \multicolumn{4}{c}{ Soil irrigated with artesian water } \\
\hline $\begin{array}{c}\text { Depth } \\
\text { (cm). }\end{array}$ & $\mathbf{F e}$ & $\mathbf{M n}$ & $\mathbf{Z n}$ & $\mathbf{C u}$ & $\mathbf{C o}$ & $\mathbf{N i}$ & $\mathbf{P b}$ & $\mathbf{F e}$ & $\mathbf{M n}$ & $\mathbf{Z n}$ & $\mathbf{C u}$ & $\mathbf{C o}$ & $\mathbf{N i}$ & $\mathbf{P b}$ \\
\hline $0-5$ & 0.37 & 0.49 & 0.57 & 0.48 & 0.88 & 0.70 & 0.60 & 0.27 & 0.61 & 0.82 & 0.45 & 0.73 & 0.20 & 0.62 \\
$5-10$ & 0.33 & 0.43 & 0.54 & 0.42 & 0.82 & 0.76 & 0.42 & 0.18 & 0.93 & 0.59 & 0.67 & 0.71 & 0.57 & 0.66 \\
$10-30$ & 0.32 & 0.30 & 0.57 & 0.50 & 0.52 & 0.85 & 0.43 & 0.23 & 0.46 & 0.37 & 0.83 & 0.94 & 0.51 & 0.43 \\
$30-60$ & 0.19 & 0.32 & 0.47 & 0.35 & 0.29 & 0.73 & 0.57 & 0.21 & 0.49 & 0.35 & 0.41 & 0.43 & 0.11 & 0.38 \\
$60-90$ & 0.26 & 0.18 & 0.92 & 0.46 & 0.52 & 0.59 & 0.57 & 0.09 & 0.37 & 0.72 & 0.51 & 0.15 & 0.14 & 0.46 \\
$90-150$ & 0.12 & 0.13 & 0.47 & 0.25 & 0.80 & 0.60 & 0.24 & 0.04 & 0.24 & 0.23 & 0.17 & 0.15 & 0.32 & 0.53 \\
\hline
\end{tabular}

${ }^{*}$ Available index ratio $\mathrm{AIR}=$ Available heavy metals/Total heavy metals) 
These results coincide with those of (Dumontet et al. 1990 and El-Gendi et al. 1997) who found that irrigating sandy soil in the Abou- Rawash area with drainage water increased total $\mathrm{Cu}, \mathrm{Zn}$ and $\mathrm{Fe}$, which reached 125,170 and 5 times that of the virgin soil in the same area. It seems that the high permeability of the calcareous soil in Borg Elarab area, besides the colloids state of the suspended matter, facilitates the downward movement of heavy metals (ionic, complexed with organic molecules and /or finely dispersed colloidal).

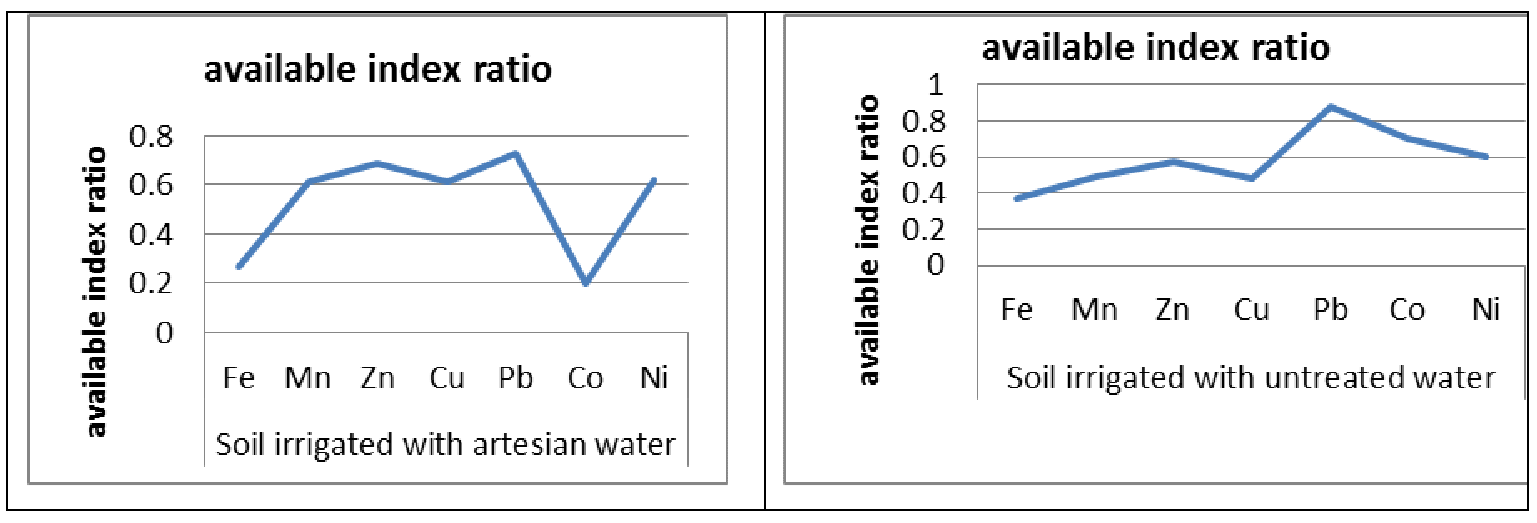

Fig(2). Available index ratio in soils irrigated with artesian and wastewater

\section{III- Effect of wastewater on heavy metals concentrations in potato growing in the Borg ELarab area}

Contents of $\mathrm{Fe}, \mathrm{Zn}, \mathrm{Cu}, \mathrm{Co}, \mathrm{Ni}$ and $\mathrm{Pb}$ in leaves potato plants grown on the studied areas are found in Fig. 3. Results show that, the highest values of heavy metals content were found in plants grown on soil irrigated with waste water. This coincides with the previous findings that soil contained the highest values of chemically available heavy metals (Table 3). Variation in accumulation percent of different heavy metals in potato plant arranged in the following order: $\mathrm{Cu}>\mathrm{Ni}>\mathrm{Pb}>\mathrm{Co}, \mathrm{Fe}>\mathrm{Mn} \geq \mathrm{Zn}$ (Table 4). Heavy metals are nonbiodegradable and persistent environmental contaminants, which may be uptake and then absorbed by tissues of vegetables plants (Khairiah et al. 2004; Al Jassir et al., 2005; Singh and Kumar, 2006; Sharma et al., 2008).

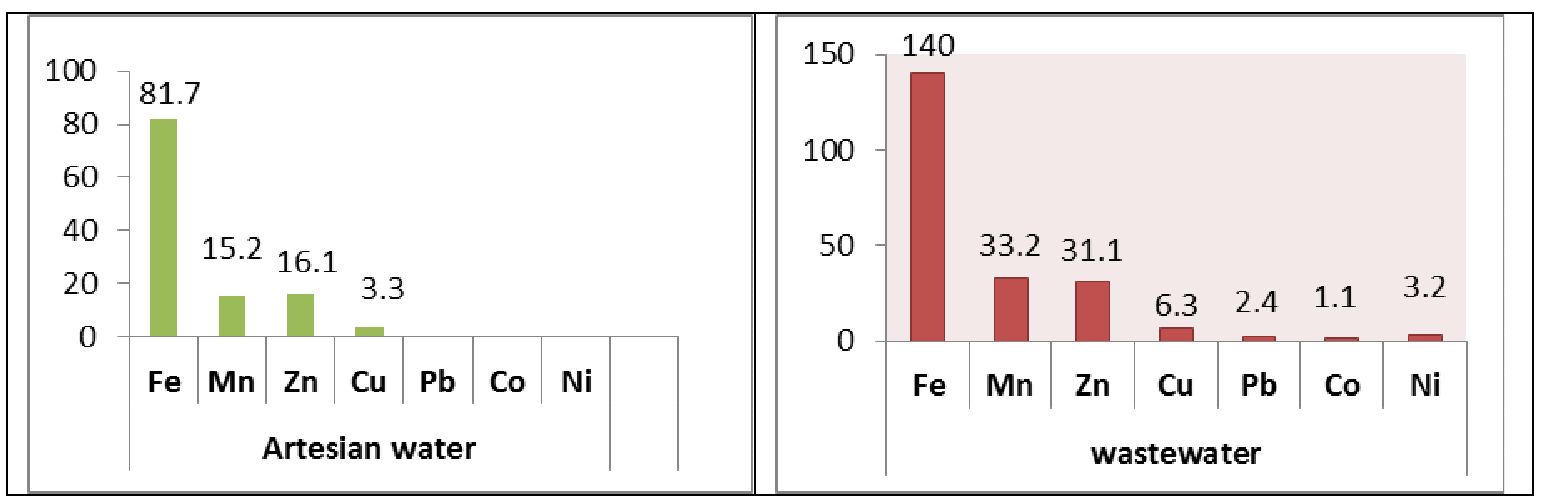

Fig (3). Heavy metals concentrations $\mathrm{mgkg}^{-1}$ in leaves of potato affected by source of water irrigation. 
Radwan and Salama (2006) studied the mean concentrations and range of heavy metals found in fresh fruits and vegetables samples from several local markets in Alexandria city, Egypt during 2005. Among vegetables, the leafy vegetables lettuce and spinach have content of $\mathrm{Pb}, \mathrm{Cd}, \mathrm{Cu}$ and $\mathrm{Zn}$ ranged between $0.28-0.65,0.05-0.09,1.82-2.22,7.80$ - 12.0; 0.23-0.43, 0.09-0.15, $3.50-5.90$ and $18.0-22.8 \mathrm{mg} / \mathrm{kg}$ dry weight, respectively. The means of $\mathrm{Pb}, \mathrm{Cd}$, $\mathrm{Cu}$ and $\mathrm{Zn}$ for lettuce and spinach were $0.58,0.07,1.97,9.76 ; 0.34,0.11,4.48$ and $20.9 \mathrm{mg} / \mathrm{kg}$ dry weight, respectively. In addition, Arora et al. (2008) reported that wastewater irrigated spinach has shown significantly higher concentrations of $\mathrm{Fe}(309 \mathrm{mg} / \mathrm{kg}), \mathrm{Mn}(69.4 \mathrm{mg} / \mathrm{kg}), \mathrm{Cu}(16.5 \mathrm{mg} / \mathrm{kg})$ and $\mathrm{Zn}$ $(33.1 \mathrm{mg} / \mathrm{kg})$, compared to the freshwater - irrigated spinach, indicating the highest metal absorption for this vegetable.

Correlation matrix between available heavy metals in soil and concentrated heavy metals in potato plant irrigated with wastewater as the same result with Correlation matrix between available index ratio in soil and concentrated heavy metals in potato plant irrigated with wastewater:

There is a significant strong correlation between the concentration of heavy metals in the soil and its concentration on the potato plants Fig 4,5.

Available index ratio in soils irrigated with wastewater relatively higher than soil irrigated with artesian these rever that the important available index ratio in these study Fig 2. Available index ratio in soils has high correlation with heavy metals concentrations in potato plants

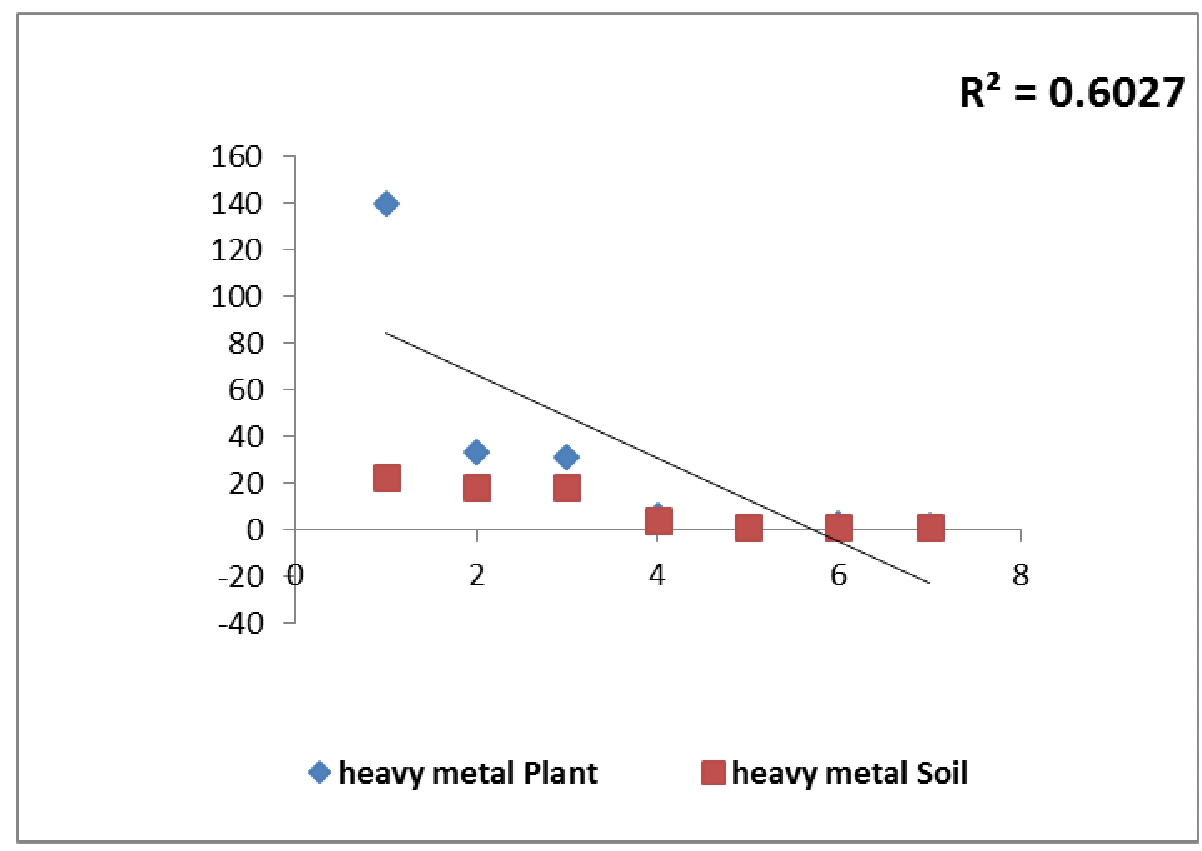

Fig (4). Available heavy metals in soil irrigated with wastewater and concentrated heavy metals potato plan 


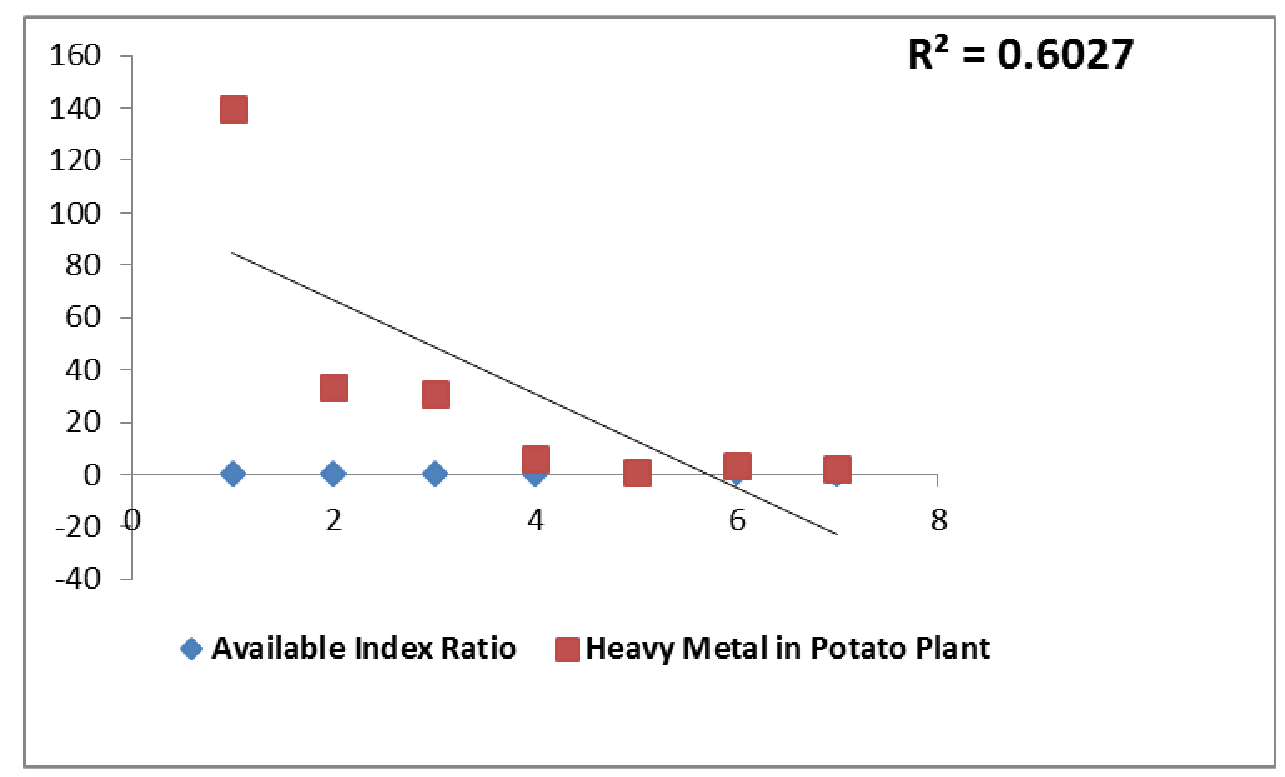

Fig (5). Available Index Ratio and concentrated heavy metals in potato plant (Available Index Ratio (AIR= Available heavy metals/Total heavy metals)

Table 4. Effect of different sources water irrigation on yield components of potato grown in Borg Elarab area

\begin{tabular}{ccc}
\hline $\begin{array}{c}\text { Irrigation } \\
\text { Water sources }\end{array}$ & $\begin{array}{c}\text { Tuber yield } \\
\left(\text { Ton ha }^{-1}\right)\end{array}$ & $\begin{array}{c}\text { Straw yield } \\
\left(\mathbf{k g ~ h a}^{-1}\right)\end{array}$ \\
\hline Artesian water & 9.425 & 8.905 \\
Wastewater & 7.820 & 6.642 \\
\hline
\end{tabular}

The shoots in potato plants grown in soils irrigated with artesian water were higher than soil irrigated with Wastewater respectively. Indicating that the tuber yield was more than the straw yield in soil irrigated with Wastewater Table 4

\section{Conclusions}

This depth is practically within the blow layer. If the soil still irrigated with this water for the long time, the root zone could be polluted with $\mathrm{Zn}, \mathrm{Cu}, \mathrm{Ni}$ and $\mathrm{Pb}$. The increasing extractability of the concerned heavy metals in the soil irrigated with wastewater could be attributed to increasing the total contents of profiles. The highest values of heavy metals content were found in potato plants grown on soil irrigated with wastewater.

\section{Acknowledgement}

The authors would like to express great thanks to the Soil, Water and Environment Research Institute and Institute of Environment Studies Research Ain Shams University, Egypt. 


\section{REFERENCES}

Abbas, S. T. M. Sarfraz, S.M. Mehdi, G. Hassan, and O. Ur-Rehman (2007). Trace elements accumulation in soil and rice Plants irrigated with the contaminated water. Soil and Tillage Research, 94: 503-509.

Abdel - Sabour, M. E., A. A. Mohamed, and A. O. Abd El -Nabi (2000). Heavy metals accumulation in rice sorghum crops grown on contaminated soils in Egypt. Minufiye J. Agric Res, 25 (4): 1157

Abdel- Tawab M. M. (1985). Soil pollution as effected by some industrial waste at Helwan, El- Saff area. M. Sc.Thesis. Fac.of Agric. Cairo University Egypt

Abd-El-Naim, E.M. and R. M. El-Awady (1989).Studies on heavy metals removal from sewage water used in sandy soils toxic substances in agricultural water supply and drainge 2nd pan. American ICID Reional Conference (1989). 219 -230

Abdelrazek S. A. E. (2014). Effect of Wastewater Irrigation on Plant Enzymes and Soil Health Assessment in Borg Elarab Region, ph.D A thesis University of Sadat City. ttp://t1t.net/book/index.php?action=view\&id=2070

Abdelrazek S. A. E. (2007). Effect of agricultural periods and farming practices on sustainable soil health in some new reclaimed soils, ARE. Egypt .

$\mathrm{Mg} \quad \mathrm{Sc}$ Thesis, Res Institute, Ain Shamis Univ http://t1t.net/book/index.php?action=view\&id=2073

Al-Jassir, M.S., A.Shaker and M. A. Khaliq (2005). Deposition of heavy metals on green leafy vegetables sold on roadsides of Riyadh city, Saudi-Arabia Bull. Environmental Contamination and Toxicology, 75: 1020-1027.

Al-Lahham, O., N.M. Assi, and M. Fayyad (2003).Impact of treated waste water irrigation on quality attributes and contamination of tomato fruit. Agricultural Water management Journal, 61:51-62.

Arora, M., B. Kiran, S Rani, A. Rani, B. Kaur, and N.Mittal (2008). Heavy metal accumulation in vegetables irrigated with water from different sources. Food Chemistry, 111:811-815.

Chang, A. C., J. E. Warneke, A.L. Page, and L .J. Lund (1984). accumulation of heavy metals in sewage sludge treated soils. J. Environ. Qual., 13:8791.

Day, A.D., J. A. McFadyen, T. C. Tucker and C.B. Gluff (1979).Commercial production of wheat grain irrigated with municipal wastewater and pump water. j. Environ, Qual., 8; 403 -406.

Dumoutet S., M. Levesque, and S. P. Mathur (1990). Limeted downward migration of pollutant metals $(\mathrm{Cu}, \mathrm{Zn}, \mathrm{Ni}$ and $\mathrm{Pb}$ ) in acidic virgin peat soil near a smelter. Water, Air and Soil Pollution, 49: 329

EL- Nennah, M., T. El-Kobbia, A. Shahate, and I. El-Gamal (1982). Effect of irrigation loamy sand soil by sewage effluents on its content of some nutrients and heavy metals. Plant and Soil, 65: 289-292.

Elgala, A.M., M.A.O. Elsharawy and M.M. Elbordiny (2003). Impact of sewage water used for irrigation on soil characteristics and heavy metals composition of some grown crops . Egypt J. Soil Sci., 43 : 405-419. 
El-Gendi, S. A., S.H. Badawy, and M.I.D. Helal (1997). Mobility of some heavy metal nutrients in sandy soils irrigated with sewage effluent. J. Agric. Sci. Mansoura Univ., 22: 3535

Elsokkary I. H. (1980). Contamination of edible parts of seven plant crops and soils by heavy metals in urban areas by air pollution in Alexandria distract, Egypt, In Atmospheric Pollution. Proceeding of the 14th Init Collogium, Paris, France, May 1980, M. M. Benarie (Ed), Studies in Environ. Sci. Elsevire Sci. Pul., pp. $43-438$.

Fair G. M., J.C. Geyer, and D. A. Okun (1971). Elements of water supply and wastewater supply disposal. Willey and Sone, New York P. 752

FAO (1976).Soil survey investigations for irrigation Soil Bull. 42, Rome

Hinesly T. D., E.L. Ziegler, and G.L. Barrett (1979).Residual effects of irrigation corn with digested sewage . J. Environ. Qual. 8: 35 - 38.

Idown, O.S., E.S.H. Van R.Schindelbeck, G. Abawi, D. Wolfe, J. Thies, B. Guginob,B. Moebius, and D. Clune (2007). The new cornal soil health test and protocols and interpretation what's cropping up 17, (1) $6-7$ (http.j) w.w.w css Cornell .edu/ extension/ wcu/voll7No12007 jan-Feb.pdf

Jackson M.L. (1958). Soil Chemical Analysis. Prentic- Hall, Inc. Englewood Cliffs, N.J. Library of Congress, USA

Khairiah, T., M. K. Zalifah, Y. H. Y. H. Yin, and A. Aminath (2004). The uptake of heavy metals by fruit type vegetables grown in selected agricultural areas Pakistan Journal of Biological Sciences, 7(2): 14381442.

Khalil, M.E. (1990). Accumulation of some nutrients and heavy metals in Abu Rawash area, Giza Governorate. M.Sc. Thesis, Fac. Agric., Moshtohor, Zagazig Univ., Egypt

Lindsay, W.L. and W.A. Norvell (1978). Development of DTPA soil test for zinc, iron, manganese and copper. Soil Sci. Soc. Am. J., 42: 421-426.

Madrid, F., R. Lopez, and F. Cabrera (2007).Metal accumulation in soil after application municipal solid waste compost under intensive farming conditions. Agric. Ecosystems Environ. 119: 249-256.

Fattah, M. K. and S. A. E. Abdelrazek (2014). The Improvement of the Quality of Irrigation Water Contaminated with Heavy Metals in the Borg El Arab, Egypt. Journal of Water Resource and Protection, 6: 1703-1715 http://www.scirp.org/journal/articles.aspx?searchCode=Mohamed+Kamel + Fattah\&searchField=authors\&page $=1$

Pescod, M.D. (1992). Wastewater treatment and use in agriculture. FAO Irrigation and Drainage Paper no 47, Food and Agriculture Organization of the United Nations, Rome, Italy, $125 \mathrm{pp}$

Radwan M. A. and A. K. Salama (2006). Market basket survey for some heavy metals in Egytian fruits and vegetables. Food and Chemical Toxicology, 44: 1273- 1278 .

Rawa, G. J. (1973). Food Analysis by Atomic Absorption Spectroscopy Varion. Techtrom. Australia. U.S.A. Switzerland pp.89

Richards, R.L. (1954). Diagnosis and improvement of saline and alkali soils. In Richards, R.L. ed, Agriculture Hand Book No.60, U.S Government Printing Office, Washington, USA. 
Sharma, R. K., M. Agrawal, and F. M. Marshall (2008).Atmospheric depositions of heavy metals $(\mathrm{Cd}, \mathrm{Pb}, \mathrm{Zn}$, and $\mathrm{Cu})$ in Varanasi city, India.Environmental Monitoring and Assessment, 142 (1-3): 269-278

Shouman, A.E.M. (2015). risk assessment of industrial waste water irrigation on the physiology of some vegetable crops, PH.D A thesis University of Ain Shams.

Singh, S. and M.Kumar (2006). Heavy metal load of soil, water and vegetables in peri- urban. Delhi. Environmental Monitoring and Assessment, 120:7991.

UNEP/GEMS(1995). Global environment outlook. New York, Oxford University Press., p: 13-209.

WHO (World Health Organization) (1993). Guidelines for Drinking-water Quality. Volume 1: Recommendations, 2nd edn. World Health Organization, Geneva, Switzerland, $188 \mathrm{pp}$

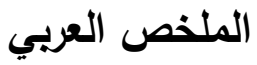

صلاحية المعادن الثقيلة في اراضى برج العرب وامتصاصها بنباتات البطاطس

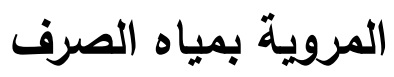

سعد عبد الصمد السيد عبد الرازق" و احمد ابراهيم محمود شومان **

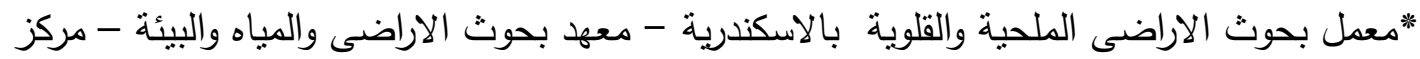

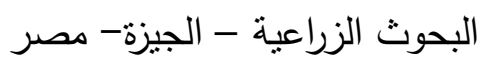

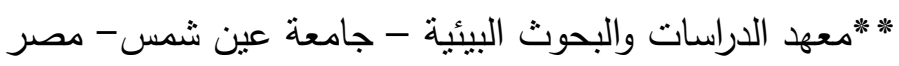

زادت مخلفات الصرف الناتجة عن الأنشطة البشرية، بشكل ملحوظ مما أدى إلى زيادة مشكلة التخلص منها ،

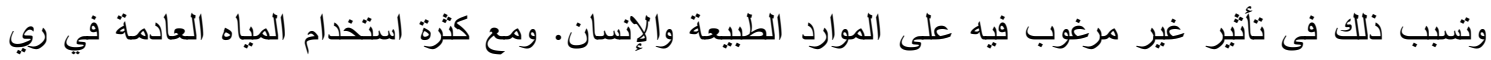

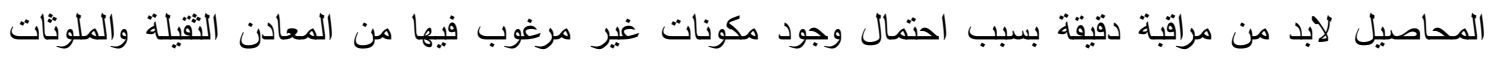

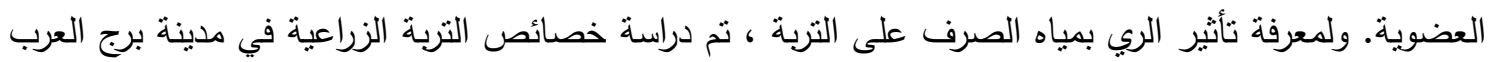

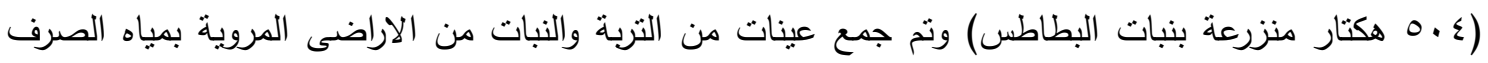

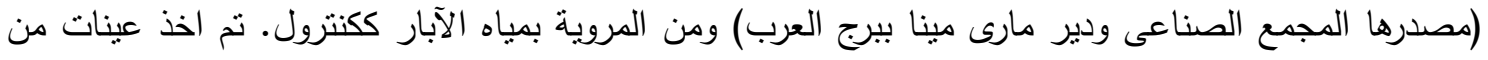

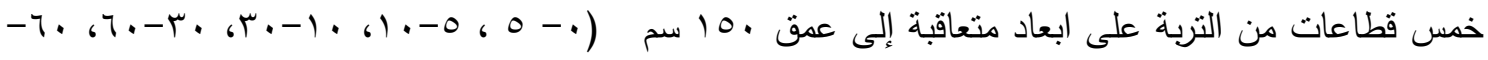

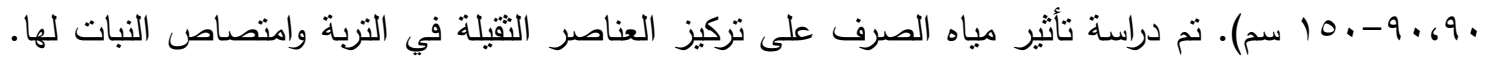

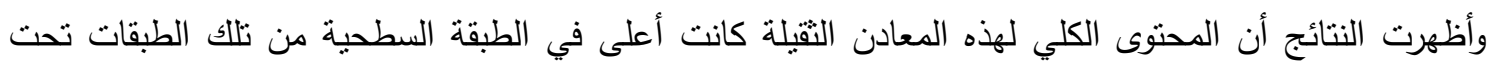

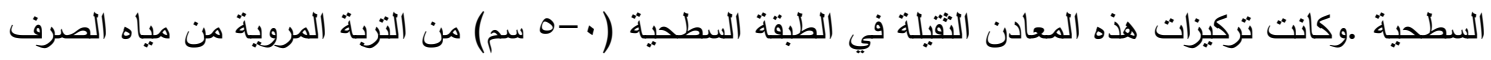

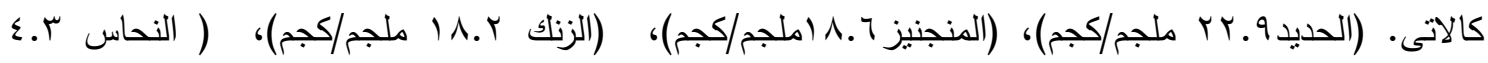

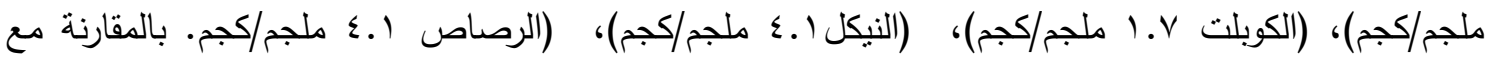


التربة المروية بمياه الآبارعلى التوالي وهى ( الحديده.1 ملجم/كجم)، (المنجنيز ؟.. ملجم/كجم)، (الزنك ا.

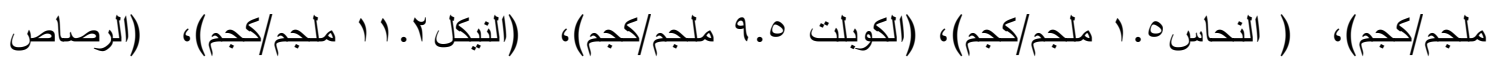
ץ.11 ملجم/كجم. تجاوز مجموع المعادن الثقيلة في الطبقة السطحية الحدود المسموح بها فى التربة المروية بمياه الصرف. وأظهرت الدراسة أن. نباتات البطاطس المزروعة في التربة وفقا لقدرتها على تراكم المعادن التقيلة كما في الترتيب التالي البطاطس المروية بمياه صرف اكثر فى تراكم العناصر الثقيلة من البطاطس المروية بمياه البئر وإختلاف تركيز المعادن التقيلة فى البطاطس المرواه بمياه الصرف وفقا للترتيب التالي:النحاس > النيكل > بلنيل الرصاص > الكوبلت والحديد > المنجنيز > الزنك ـ بجانب التراكم المفرط للكوبلت، النيكل والرصاص فى نبات البطاطس المروى بمياه الصرف.

الكلمات الدلالية : معادن ثقيلة ، برج العرب ، مياه الصرف غير المعالجة ، نبات البطاطس 
